\title{
ADAM33 haplotypes are associated with asthma in a large Australian population
}

\author{
Mary-Anne Kedda ${ }^{1,2,3,4,5,6,9}$, David L Duffy ${ }^{7,9}$, Bernadette Bradley ${ }^{1,2,3,4}$, Robyn E O'Hehir ${ }^{1,8}$ \\ and Philip J Thompson*,1,2,3
}

\begin{abstract}
${ }^{1}$ The Co-operative Research Centre (CRC) for Asthma, Sydney, Australia; ${ }^{2}$ The Asthma and Allergy Research Institute (Inc.), Sir Charles Gairdner Hospital, Nedlands, Western Australia, Australia; ${ }^{3}$ The Centre for Asthma, Allergy and Respiratory Research, University of Western Australia, Western Australia, Australia; ${ }^{4}$ The Western Australian Institute for Medical Research and Centre for Medical Research, Perth, Australia; ${ }^{5}$ School of Public Health, Queensland University of Technology, Brisbane, Australia; ${ }^{6}$ School of Life Sciences and Institute of Health and Biomedical Innovation, Queensland University of Technology, Brisbane, Australia; ${ }^{7}$ Genetic Epidemiology Laboratory, Queensland Institute of Medical Research, Brisbane, Australia; ${ }^{8}$ Department of Allergy, Immunology and Respiratory Medicine,

The Alfred Hospital and Monash University, Melbourne, Australia
\end{abstract}

The ADAM33 gene has recently been identified as being a potentially important asthma candidate gene, and polymorphisms in this gene have been shown to be associated with asthma and bronchial hyperresponsiveness in Caucasian individuals from several populations. We performed chip-based matrixassisted laser desorption/ionisation time-of-flight (MALDI-TOF) mass spectrometry using the MassARRAY system and multiplexed genotyping assays to investigate the association between 10 single nucleotide polymorphisms (SNPs) in the ADAM33 gene $\left(\mathrm{F}_{-}+1, \mathrm{Q}_{-}-1, \mathrm{~S}_{-} 1, \mathrm{ST}_{-}+4, \mathrm{ST}_{-}+7, \mathrm{~V}_{-}-2, \mathrm{~V}_{-}-1, \mathrm{~V}_{-} 2, \mathrm{~V}_{-} 4\right.$, $\left.\mathrm{V} \_5\right)$ and asthma and asthma severity in a large Australian Caucasian population of nonasthmatic controls $(n=473)$, and patients with mild $(n=292)$, moderate $(n=238)$ and severe $(n=82)$ asthma. No significant association was found between any one of the $10 \mathrm{SNPs}$ and asthma or asthma severity, however, there was a significant global haplotypic association with asthma $(P=0.0002)$ and disease severity $(P=0.0001)$, driven by the combination of two key SNPs, $V_{-}-1$ and $S T_{-}+7$. A meta-analysis of all the genetic studies conducted to date found significant between-study heterogeneity, likely to reflect population stratification. Our analysis of ADAM33 haplotypes further suggests a likely role for ADAM33 in the asthma phenotype, although it does not exclude an association with another locus in linkage disequilibrium with ADAM33.

European Journal of Human Genetics (2006) 14, 1027-1036. doi:10.1038/sj.ejhg.5201662; published online 14 June 2006

Keywords: polymorphism; MALDI-TOF; asthma; ADAM33; haplotype

\footnotetext{
*Correspondence: Professor PJ Thompson, Asthma and Allergy Research Institute, Ground Floor E Block, Sir Charles Gairdner Hospital, Nedlands, WA, 6009, Australia.

Tel: +61 (0)8 9346 3198; Fax: +61 (0)8 9346 4159;

E-mail: aari@aari.uwa.edu.au

${ }^{9}$ These authors contributed equally to this paper

Received 22 June 2004; revised 7 March 2006; accepted 13 April 2006; published online 14 June 2006
}

Introduction

Asthma is a common disorder, characterised by airflow obstruction, bronchial hyperresponsiveness (BHR) and airway inflammation. ${ }^{1}$ Individuals with chronic asthma often develop irreversible structural changes in their airways from abnormal repair and remodelling processes. ${ }^{2}$ Airway remodelling is associated with epithelial damage, smooth muscle hyperplasia and increased matrix deposition $^{3}$ and these structural changes are likely to be 
associated with some of the symptoms of asthma, ${ }^{4}$ including suboptimal responses to corticosteroids, persistent BHR and progressive decline in lung function in asthmatics with severe and/or chronic disease. ${ }^{5}$ It has been suggested that airway remodelling is a consequence of an aberrant injury/repair response driven by the inflammatory process, ${ }^{6}$ hence the genes encoding molecules modulating the injury/repair response are potentially good candidates for so-called asthma genes.

The ADAM (a disintegrin and a metalloproteinase) family is a subgroup of the metzincin metalloproteinase superfamily, implicated in cell-cell and cell-matrix interactions, ${ }^{7}$ cell migration, cell adhesion ${ }^{8}$ and signal transduction, ${ }^{9,10}$ and responsible for the proteolytic removal of extracellular domains of numerous transmembrane proteins in a process known as ectoderm shedding. ${ }^{11}$ ADAM17, or TACE (TNF $\alpha$-converting enzyme), is responsible for the cleavage of the membrane-bound form of $\mathrm{TNF} \alpha$ to release the active cytokine, and is the most extensively studied member of the ADAM family. ${ }^{12}$

ADAM33 has been shown to be expressed in lung fibroblasts and bronchial smooth muscle $\mathrm{e}^{13,14}$ and the protein has been detected in lung tissue, smooth muscle cells and fibroblasts. ${ }^{15}$ Recently, several polymorphisms in the ADAM33 gene have been shown to be significantly associated with asthma, $\mathrm{BHR}^{13}$ and atopy. ${ }^{16}$ Taken together, these findings suggest an important role for ADAM33 in airway remodelling and hence asthma. ${ }^{13}$

We sought to confirm the association between polymorphisms in the ADAM33 gene and asthma, and to examine the association with disease severity, in a large Australian Caucasian population of nonasthmatic controls and patients with mild, moderate and severe asthma, using high throughput MALDI-TOF mass spectrometry and the MassARRAY multiplex genotyping system. ${ }^{17}$

\section{Materials and methods Subjects}

The case-control population recruited for the association study has been described elsewhere, in a study protocol approved by the Human Research Ethics Committee of the Sir Charles Gairdner Hospital, Western Australia. ${ }^{18}$ Briefly, 612 patients with asthma and 473 nonasthmatic controls participated in this study. The sample was ethnically homogeneous. All patients were Caucasian and the country of birth of all four grandparents was known for $50 \%$ of subjects. Of all grandparents, 96\% came from Northern Europe or Australia. Asthma was defined as doctor-diagnosed asthma and the nonasthmatic control subjects had no history of asthma. All participants were unrelated and between 18 and 89 years of age, all gave written informed consent and completed a comprehensive questionnaire, which assisted in phenotype assessment. Approximately $15 \mathrm{ml}$ of blood were obtained from each participant, followed by assessment of lung function by spirometry, and assessment of atopic status, based on a skin prick reaction (wheal $>3 \mathrm{~mm}$ ) to at least one of five common aeroallergens: cat, dog, house dust mite, mould mix and grass pollen mix.

\section{Disease severity}

Patients were allocated to different asthma severity groups using criteria slightly modified from those specified by the Australian National Asthma Council, Australia ${ }^{19}$ as well as the National Asthma Education and Prevention Program (NAEPP) Expert Panel Report. ${ }^{18,20}$

\section{DNA extraction}

Genomic DNA was extracted from blood buffy coats using the QIAamp DNA Blood Mini Kit (Qiagen, Hilden, Germany) and following the manufacturers' instructions.

\section{Selection of SNPs}

We selected 10 single nucleotide polymorphisms (SNPs) in the ADAM33 gene, which previously had been shown to have an allelic and/or haplotype association with asthma, including $\mathrm{F}_{-}+1$ (rs511898), Q - 1 (rs612709), S_1 (rs3918396), ST_+ 4 (rs44707), $\mathrm{ST}_{-}+7$ (rs574174), V_-2 (rs628977), V_-1 (rs543749), V_2 (rs3918400), V_4 (rs2787094), V_5 (rs3746631). ${ }^{13}$ One additional SNP previously found to be associated with asthma, ${ }^{13} \mathrm{~V}_{-}-3$ (rs628977) did not assay successfully, however, given the moderate to strong levels of Linkage disequilibrium (LD) of SNPs previously documented, we expected the 10 SNPs studied to capture most of the haplotypic variation.

\section{PCR amplification and genotypic analysis}

Genotyping of the 10 SNPs was performed using the MassARRAY system (Sequenom Inc., San Diego, CA, USA), commercially available through the Australian Genome Research Facility (Brisbane, Australia). Using the unique rs accession numbers, SNP details and sequence data are available through NCBI databases (www.ncbi.nlm.nih. gov). Briefly, following PCR amplification, primer extension products were analysed by chip-based MALDI-TOF mass spectrometry. Primers were designed using Sequenom software and the extension reaction produced allelespecific extension products with masses differing by $\sim 300 \mathrm{Da}$, or approximately a single nucleotide. Primer extension and PCR were performed according to the manufacturer's instructions, using AmpliTaq DNA polymerase (Perkin-Elmer, CA, USA). After desalting of the reaction products (SpectroCLEAN, Sequenom), approximately $10 \mathrm{nl}$ were loaded into a SpectroCHIP (Sequenom) and analysed in the fully automated mode with the MALDI-TOF MassARRAY system (Sequenom). SpectroTYPER software (Sequenom) automatically called genotypes and only conservative and moderate calls were accepted for this study. 


\section{Statistical analyses}

Genotype and allele frequencies were calculated for each patient group. Initial analyses compared the SNP allele frequencies across the nonasthmatic controls and varying asthma severity (mild, moderate and severe asthma) using ordinal logistic regression analysis. LD between the markers was calculated as Lewontin's D',using Cocaphase. ${ }^{21}$ Models were fitted both including and excluding covariates, including age, gender and smoking status.

Association was assessed under a multiplicative penetrance model, comparing haplotypes spanning all 10 SNPs between controls and cases, present at a frequency of at least $0.5 \%$, and statistical significance assessed via a permutation procedure. Haplotype-based analysis was performed using the scoring approach of Schaid et al, ${ }^{22}$ as implemented in the R-statistical language. ${ }^{23}$ and using Cocaphase. ${ }^{21}$ Under the scoring approach of Schaid et al, ${ }^{22}$ the probability of each possible haplotype for each individual is inferred using an EM algorithm and these probabilities are weighted and used to perform logistic regression analysis with haplotype as the predictive variable. This approach avoids problems implicit in assigning each person a definite haplotype when phase is unknown. Cocaphase $^{21}$ also uses an EM approach to establish haplotype probabilities for each person. The score-based global or omnibus test for haplotypic association included all haplotypes with a frequency above $0.5 \%$ in the analysis and therefore did not suffer from the problem of multiple tests. If the global test was significant, we then performed subhaplotype analysis to infer which SNPs were important in driving the association. A simulation-based $P$-value gets around the problem of missing data biasing the results. Analysis of disease severity included the controls/nonasthma group as we were looking for a dose-response effect. Exact conditional testing for association between asthma and unphased genotypes at multiple SNPs was performed using importance sampling for the appropriate log-linear model. ${ }^{24,25}$
For the meta-analysis, we extracted haplotype frequencies from two other studies that published these frequencies $^{16,26}$ and combined them with our study in a log-linear analysis.

\section{Results}

In total, 612 patients with asthma and 473 nonasthmatic controls participated in this study. All patients were unrelated and Caucasian in origin, and patients with asthma were subdivided by disease severity as described elsewhere. ${ }^{18}$ Table 1 illustrates the demographics of the population. All groups had similar age and gender distributions, although the asthma group as a whole had a significantly higher percentage of atopic subjects (83\%) when compared to the nonasthmatic control group (51\%) $(P<0.0001)$. Daytime symptoms of asthma occurred, on average, between 3.9 times per week in individuals with mild asthma, 6.8 times per week in individuals with moderate asthma, and nine times per week in individuals with severe asthma. Less than half the patients with mild asthma awoke from sleep owing to their asthma, whereas all patients with severe asthma woke from sleep most nights owing to their asthma. Unplanned visits to the family doctor for asthma over the previous 12 months varied between 0.51 per year in patients with mild asthma, 1.4 per year in patients with moderate asthma, and 4.2 per year in patients with severe asthma. Hospital admissions over the previous 12 months occurred in less than $5 \%$ of patients with mild asthma, in $30 \%$ of patients with moderate asthma, and in $70 \%$ of patients with severe asthma. Smoking history was obtained for all participants and nonsmokers comprised $47 \%$ of the nonasthmatics, and 38, 40 and 33\% of the mild, moderate and severe asthmatics, respectively.

Ten SNPs in the ADAM33 gene, previously shown to be associated with asthma in UK and US populations, ${ }^{13}$ were screened using high throughput MALDI-TOF mass

Table 1 Demographics of the study population

\begin{tabular}{|c|c|c|c|c|c|c|c|c|c|c|}
\hline Phenotype & $n$ & $\begin{array}{c}\text { Females } \\
(\%)\end{array}$ & $\begin{array}{l}\text { Atopy } \\
\text { (\%) }\end{array}$ & $\begin{array}{c}\text { Mean age } \\
\text { (years } \pm S D)\end{array}$ & $\begin{array}{c}\% \text { Predicted } \\
\text { FEV } \\
\text { (mean } \pm \text { SEM) }\end{array}$ & $\begin{array}{c}\text { Oral } \\
\text { corticosteroids }^{\mathrm{a}} \\
(\%)\end{array}$ & $\begin{array}{c}\text { Frequency of } \\
\text { oral } \\
\text { corticosteroid } \\
\text { use (mean } \\
\text { times/year) }\end{array}$ & $\begin{array}{l}\text { Inhaled } \\
\text { corticosteroids } \\
(\%)\end{array}$ & $\begin{array}{c}\text { Mean inhaled } \\
\text { steroid dose } \\
\text { (mcg/day } \\
\pm \text { SEM) }\end{array}$ & $\begin{array}{c}\beta_{2^{-}} \\
\text {adrenoceptor } \\
\text { agonists } \\
(\%)\end{array}$ \\
\hline Nonasthma & 473 & 56 & 51 & $50.6 \pm 14.2$ & $101.7 \pm 2.5$ & Nil & Nil & Nil & Nil & Nil \\
\hline All asthma & 612 & 63 & 83 & $49.0 \pm 15.5$ & - & - & - & - & - & - \\
\hline Mild asthma & 292 & 61 & 84 & $47.3 \pm 15.1$ & $92.2 \pm 1.0$ & 5 & 1.3 & 59 & $890 \pm 49$ & 82 \\
\hline $\begin{array}{l}\text { Moderate } \\
\text { asthma }\end{array}$ & 238 & 64 & 81 & $50.8 \pm 15.9$ & $74.2 \pm 1.4$ & 38 & 1.5 & 95.6 & $1474.5 \pm 65$ & 94.3 \\
\hline $\begin{array}{l}\text { Severe } \\
\text { asthma }\end{array}$ & 82 & 65 & 78 & $50.1 \pm 13.6$ & $59.7 \pm 2.6$ & 79 & 2.9 & 98.2 & $2729.2 \pm 165$ & 97.5 \\
\hline
\end{tabular}

a Percentage of patients who had used oral corticosteroids in last 12 months.

bercentage of patients using inhaled corticosteroids.

${ }^{\mathrm{C}}$ Beclomethasone equivalent.

dPercentage of patients using $\beta_{2}$-adrenoceptor agonists. 
spectrometry and the Sequenom MassARRAY system. A maximum of four-plex analysis was achieved (V_5, V_4, $\mathrm{S} \_1$ and $\left.\mathrm{Q}-1\right)$, with one three-plex $\left(\mathrm{V}_{-} 2, \mathrm{ST}_{-}+7, \mathrm{~F}_{-}+1\right)$, one two-plex $\left(\mathrm{V}_{-}-1, \mathrm{~V}_{-}-2\right)$ and one uni-plex $\left(\mathrm{ST}_{-}+4\right)$. Approximately, $92 \%$ of the calls were conservative on the first run, with approximately $8 \%$ of the remaining calls, conservative or moderate on repeat measurement (respotting). Less than $1 \%$ of samples required a repeat PCR amplification. All the previously described polymorphisms were present in our population, with minor allele frequencies between 3 and 36\% (Table 2).

The total population was in Hardy-Weinberg Equilibrium for most SNPs studied (Table 2), as were the separate case and control populations, and LD was strong for all markers (Table 3), with only two exceptions: V_4 and V_5 were not in strong LD, despite being closely positioned; and ST +7 was in LD with all other markers, with the exception of its closest marker, $\mathrm{ST}+4$, as shown previously. ${ }^{16,27}$ Initial analysis of the SNP allele frequencies in controls, mild, moderate and severe asthma, using an ordinal logistic regression model (Table 2), revealed that most of the allele frequencies were similar to those reported in other Caucasian populations (Table 4), and there was no association between any one of the polymorphisms and asthma or asthma severity in our population. Importantly, however, certain haplotypes (Table 5a) were found to be significantly associated with asthma, and the score-based omnibus test for haplotypic association was highly significant, showing an association with asthma (permutation $P=0.0002$, based on 10000 simulations) and asthma severity score (permutation $P=0.0001$ ). We then examined shorter haplotypes to determine if the result was due to particular subsets of SNPs. Using a sliding window of up to four consecutive SNPs, illustrated in Figure 1, the strongest association with asthma was with $\mathrm{V} \_2$ to $\mathrm{ST} \_+7$ $(P=0.0004)$; the best window of three SNPs spanned V_4 to $\mathrm{V}_{-}-1(P=0.004)$, with a second smaller distinct peak over $\mathrm{S} \_1$ to $\mathrm{F}_{-}+1(P=0.01)$. When we excluded controls from our analysis of severity, the association score test was not significant $(P=0.90)$, suggesting that the association was with asthma susceptibility, rather than with disease severity. Using a sliding window of up to four consecutive SNPs, illustrated in Figure 1, the strongest association with asthma was with $\mathrm{V}_{-} 2$ to $\mathrm{ST}_{-}+7(P=0.0004)$; the best window of three SNPs spanned V_4 to $V_{-}-1(P=0.004)$, with a second smaller distinct peak over $S_{-} 1$ to $F_{-}+1$

Table 2 Minor allele frequencies of SNPs in ADAM33 and association analysis in an Australian population

\begin{tabular}{|c|c|c|c|c|c|c|c|c|c|c|}
\hline \multirow[b]{2}{*}{$\begin{array}{l}\text { SNP } \\
\text { name }\end{array}$} & \multirow[b]{2}{*}{$\begin{array}{l}\text { Nucleotide } \\
\text { change }\end{array}$} & \multicolumn{3}{|c|}{ Total population } & \multicolumn{6}{|c|}{ Case-control association study } \\
\hline & & $n$ & Frequency & $\begin{array}{l}H W E^{a} \\
\text { exact } P\end{array}$ & $\begin{array}{l}\text { Nonasthmatic } \\
\text { controls }\end{array}$ & $\begin{array}{c}\text { Mild } \\
\text { asthma }\end{array}$ & $\begin{array}{l}\text { Moderate } \\
\text { asthma }\end{array}$ & $\begin{array}{l}\text { Severe } \\
\text { asthma }\end{array}$ & $\begin{array}{c}\text { Allelic } \\
\text { association } \\
\text { with asthma } \\
\text { Exact } P\end{array}$ & $\begin{array}{c}\text { Allelic } \\
\text { association with } \\
\text { severity, } \\
\text { P-value for trend }\end{array}$ \\
\hline $\mathrm{F}_{+}+1$ & $\mathrm{~T} / \mathrm{C}$ & 1014 & 0.342 & 0.889 & 0.324 & 0.360 & 0.339 & 0.377 & 0.152 & 0.289 \\
\hline$Q-1$ & $\mathrm{G} / \mathrm{A}$ & 989 & 0.160 & 0.045 & 0.162 & 0.165 & 0.160 & 0.130 & 0.821 & 0.739 \\
\hline S 1 & $\mathrm{C} / \mathrm{T}$ & 1046 & 0.110 & 0.874 & 0.112 & 0.106 & 0.113 & 0.095 & 0.691 & 0.700 \\
\hline$V_{-}-2$ & $\mathrm{~A} / \mathrm{G}$ & 1012 & 0.357 & 0.412 & 0.357 & 0.351 & 0.362 & 0.370 & 0.974 & 0.591 \\
\hline$V_{-}^{-}-1$ & $\mathrm{G} / \mathrm{T}$ & 957 & 0.139 & 0.221 & 0.144 & 0.131 & 0.145 & 0.114 & 0.578 & 0.667 \\
\hline $\mathrm{V}^{-} 2$ & $\mathrm{G} / \mathrm{A}$ & 1022 & 0.028 & 0.182 & 0.028 & 0.033 & 0.018 & 0.038 & 0.938 & 0.537 \\
\hline$V_{-}^{-} 4$ & $\mathrm{C} / \mathrm{G}$ & 1047 & 0.239 & 0.089 & 0.243 & 0.235 & 0.234 & 0.241 & 0.699 & 0.863 \\
\hline V_5 & $\mathrm{T} / \mathrm{C}$ & 1063 & 0.036 & 0.155 & 0.037 & 0.044 & 0.026 & 0.043 & 0.916 & 0.670 \\
\hline
\end{tabular}

${ }^{\mathrm{a}}$ Hardy-Weinberg equilibrium.

Table 3 Pairwise linkage disequilibria $\left(D^{\prime}\right)$ of $A D A M 33$ polymorphisms

\begin{tabular}{|c|c|c|c|c|c|c|c|c|c|c|}
\hline & $F_{-}+1$ & $Q_{-}-1$ & $S_{-} 1$ & $S T_{-}+4$ & $S T_{-}+7$ & $V_{-}-2$ & $V_{-}-1$ & $V_{-} 2$ & $V_{-} 4$ & $V_{-} 5$ \\
\hline$F_{-}+1$ & & 0.86 & 0.77 & 0.25 & 0.91 & 0.35 & 0.74 & 0.78 & 0.26 & 0.57 \\
\hline$Q^{-}-1$ & & & 0.81 & 0.07 & 0.84 & 0.56 & 0.85 & 0.84 & 0.64 & 0.87 \\
\hline S_1 & & & & 0.78 & 0.82 & 1.00 & 0.97 & 0.34 & 0.80 & 0.76 \\
\hline$S \bar{T}_{-}+4$ & & & & & 0.08 & 0.83 & 0.25 & 0.88 & 0.26 & 0.93 \\
\hline $\mathrm{ST}_{-}+7$ & & & & & & 0.28 & 0.86 & 0.91 & 0.45 & 0.90 \\
\hline$V_{-}-2$ & & & & & & & 1.00 & 0.50 & 0.23 & 0.73 \\
\hline $\mathrm{V}_{-}-1$ & & & & & & & & 0.73 & 0.65 & 0.81 \\
\hline V_2 & & & & & & & & & 0.12 & 0.81 \\
\hline$V_{-}^{-4}$ & & & & & & & & & & 0.09 \\
\hline V_5 & & & & & & & & & & \\
\hline
\end{tabular}


Table 4 Comparison of ADAM33 allele frequencies in different case-control populations

\begin{tabular}{|c|c|c|c|c|c|c|c|c|c|c|}
\hline Population & $\begin{array}{c}F_{-}+1 T / C \\
P \text {-value }\end{array}$ & $\begin{array}{l}Q_{-}-1 \mathrm{G} / \\
\text { A P-value }\end{array}$ & $\begin{array}{l}\text { S1 C/T } \\
\text { P-value }\end{array}$ & $\begin{array}{c}S T_{-}+4 \mathrm{G} / T \\
P \text {-value }\end{array}$ & $\begin{array}{c}S T_{-}+7 \mathrm{C} / T \\
P \text {-value }\end{array}$ & $\begin{array}{c}V_{-}-2 A / G \\
P \text {-value }\end{array}$ & $V_{-P \text {-value }}^{V_{\text {- }} \mathrm{G} / T}$ & $\begin{array}{c}V \text {-2 G/A } \\
P \text {-value }\end{array}$ & $\frac{V_{-} 4 \mathrm{C} / \mathrm{G}}{P \text {-value }}$ & $\begin{array}{l}\text { V_5 T/C } \\
\text { P-value }\end{array}$ \\
\hline \multicolumn{11}{|l|}{ Australian Caucasian } \\
\hline Nonasthma & 0.32 & 0.16 & 0.11 & 0.42 & 0.21 & 0.35 & 0.14 & 0.03 & 0.24 & 0.04 \\
\hline All asthma & $\begin{array}{l}0.36 \\
0.152\end{array}$ & $\begin{array}{l}0.15 \\
0.821\end{array}$ & $\begin{array}{l}0.10 \\
0.691\end{array}$ & $\begin{array}{l}0.40 \\
0.536\end{array}$ & $\begin{array}{l}0.20 \\
0.468\end{array}$ & $\begin{array}{l}0.36 \\
0.974\end{array}$ & $\begin{array}{l}0.13 \\
0.578\end{array}$ & $\begin{array}{l}0.03 \\
0.938\end{array}$ & $\begin{array}{l}0.24 \\
0.699\end{array}$ & $\begin{array}{l}0.04 \\
0.916\end{array}$ \\
\hline \multicolumn{11}{|l|}{ British Caucasian ${ }^{13}$} \\
\hline Nonasthma & 0.36 & 0.14 & 0.11 & 0.52 & 0.21 & 0.62 & 0.14 & 0.03 & 0.25 & 0.03 \\
\hline Asthma & $\begin{array}{l}0.26 \\
0.030\end{array}$ & $\begin{array}{l}0.08 \\
0.042\end{array}$ & $\begin{array}{l}0.05 \\
0.026\end{array}$ & $\begin{array}{l}0.41 \\
0.019\end{array}$ & $\begin{array}{l}0.14 \\
0.054\end{array}$ & 0.61 & $\begin{array}{l}0.06 \\
0.011\end{array}$ & 0.01 & $\begin{array}{l}0.16 \\
0.033\end{array}$ & 0.02 \\
\hline \multicolumn{11}{|l|}{ American Caucasian $^{13}$} \\
\hline Nonasthma & 0.33 & 0.17 & 0.10 & 0.43 & 0.24 & 0.65 & 0.17 & 0.06 & 0.21 & 0.05 \\
\hline Asthma & $\begin{array}{l}0.43 \\
0.240\end{array}$ & $\begin{array}{l}0.13 \\
0.665\end{array}$ & $\begin{array}{l}0.08 \\
0.787\end{array}$ & $\begin{array}{l}0.37 \\
0.515\end{array}$ & $\begin{array}{l}0.17 \\
0.341\end{array}$ & 0.67 & $\begin{array}{l}0.13 \\
0.526\end{array}$ & 0.04 & $\begin{array}{l}0.17 \\
0.558\end{array}$ & 0.02 \\
\hline \multicolumn{11}{|l|}{ Dutch $^{16}$} \\
\hline Nonasthma & - & - & 0.10 & 0.59 & 0.23 & - & 0.13 & - & 0.17 & - \\
\hline Asthma & & & $\begin{array}{r}0.07 \\
\text { NS }\end{array}$ & $\begin{array}{r}0.54 \\
\text { NS }\end{array}$ & $\begin{aligned} & 0.15 \\
< & 0.009\end{aligned}$ & & $\begin{array}{r}0.11 \\
\text { NS }\end{array}$ & & $\begin{array}{l}0.25 \\
<0.001\end{array}$ & \\
\hline African American ${ }^{16}$ & - & - & & & & - & & - & & - \\
\hline Nonasthma & & & 0.02 & 0.57 & 0.23 & & 0.29 & & 0.41 & \\
\hline \multirow[t]{2}{*}{ Asthma } & & & 0.02 & 0.64 & 0.25 & & 0.30 & & 0.41 & \\
\hline & & & NS & NS & NS & & NS & & NS & \\
\hline American Caucasian $^{16}$ & - & - & & & & - & & - & & - \\
\hline Nonasthma & & & 0.10 & 0.58 & 0.21 & & 0.14 & & 0.24 & \\
\hline \multirow{2}{*}{ Asthma } & & & 0.09 & 0.59 & 0.18 & & 0.13 & & 0.23 & \\
\hline & & & NS & NS & 0.017 & & NS & & NS & \\
\hline \multicolumn{3}{|l|}{ Hispanic $^{16}$} & & & & & & & & - \\
\hline Nonasthma & - & - & 0.04 & 0.63 & 0.09 & - & 0.11 & - & 0.13 & \\
\hline \multirow[t]{2}{*}{ Asthma } & & & 0.04 & 0.59 & 0.10 & & 0.12 & & 0.19 & \\
\hline & & & $N S$ & NS & NS & & NS & & NS & \\
\hline Puerto Rican ${ }^{37}$ & - & - & & - & - & - & & - & & - \\
\hline \multirow{3}{*}{$\begin{array}{l}\text { Nonasthma } \\
\text { Asthma }\end{array}$} & & & 0.06 & & & & 0.16 & & 0.24 & \\
\hline & & & 0.07 & & & & 0.19 & & 0.28 & \\
\hline & & & 0.427 & & & & 0.277 & & 0.297 & \\
\hline \multicolumn{11}{|l|}{ Mexican $^{37}$} \\
\hline \multirow{3}{*}{$\begin{array}{l}\text { Nonasthma } \\
\text { Asthma }\end{array}$} & - & - & 0.03 & - & - & - & 0.14 & - & 0.17 & - \\
\hline & & & 0.03 & & & & 0.13 & & 0.16 & \\
\hline & & & 1.000 & & & & 1.000 & & 0.537 & \\
\hline \multicolumn{11}{|l|}{ German $^{27}$} \\
\hline Nonasthma & 0.39 & 0.15 & 0.09 & 0.40 & 0.22 & - & 0.14 & - & 0.22 & - \\
\hline \multirow{2}{*}{ Asthma } & 0.30 & 0.11 & 0.09 & 0.33 & 0.10 & & 0.08 & & 0.19 & \\
\hline & 0.082 & 0.461 & 0.838 & 0.162 & 0.008 & & 0.147 & & 0.483 & \\
\hline
\end{tabular}

$\mathrm{NS}=$ not significant

$(P=0.01)$. Closer examination of genotype counts at these SNPs revealed that the association signal was being driven by two SNPs, $V_{-}-1$ and $\mathrm{ST}_{-}+7$. A log-linear model testing for association of joint (unphased) genotype at these two SNPs with asthma obtained an empirical $P=0.00016$ (10000 Monte Carlo Markov Chain iterations, see Table $5 \mathrm{~b}$ ). The greatest difference between asthmatics and nonasthmatics was in the number of $\mathrm{V}_{-}-1 \mathrm{~T}$ alleles present on a ST_+ 7 CC background (rows 3 and 4 of Table $5 \mathrm{~b}$ ).

Further considering the American, ${ }^{16}$ Dutch $^{16}$ and our Australian Caucasian populations, the five most common haplotypes occurring in our population appeared in the same ranking of frequency in other Caucasian populations (Table 6). Meta-analysis of the shared haplotypes in our Australian population, and the Dutch and US Caucasian populations, ${ }^{16}$ found the differences in haplotype frequen- cies to be significant $(P=8.44 \mathrm{e}-13)$, with a highly significant overall association with asthma $(P=7.14 \mathrm{e}-03)$. However, this $P$-value is driven by the rare haplotypes described in our Australian population, since if we analysed only the five most common haplotypes, the differences in haplotype frequencies were no longer significant $(P=0.17)$ and there was almost no overall association with asthma $(P=0.06)$.

There was no association with atopy $(P=0.396)$ and there was no association between genotype and smoking, nor did an adjustment for age and gender alter these results.

\section{Discussion}

We have used medium-throughput MALDI-TOF mass spectrometry and the MassARRAY system to screen ten 
Table 5a Associations between haplotypes and asthma and atopy in an Australian Caucasian population

\begin{tabular}{|c|c|c|c|c|}
\hline \multirow[b]{2}{*}{ Haplotype $^{\mathrm{a}}$} & \multicolumn{2}{|c|}{ Frequency } & \multicolumn{2}{|c|}{ P-values } \\
\hline & Asthma $(n=612)$ & Nonasthma $(n=473)$ & Asthma $(P)$ & Atopy (P) \\
\hline GCGAGCCCCA & 0.31 & 0.34 & 0.310 & 0.642 \\
\hline GCGCGTCCCA & 0.15 & 0.17 & 0.155 & 0.518 \\
\hline ACGAGCCСCA & 0.12 & 0.10 & 0.114 & 0.858 \\
\hline GCGCGTCCGA & 0.10 & 0.10 & 0.097 & 0.701 \\
\hline ATAAACACGA & 0.08 & 0.09 & 0.085 & 0.033 \\
\hline АCGCATCCCA & 0.04 & 0.05 & 0.041 & 0.880 \\
\hline GCGCGCCCCA & 0.02 & 0.02 & 0.024 & 0.180 \\
\hline GCGAGTCCCA & 0.03 & 0.01 & $0.022^{\mathrm{b}}$ & 0.163 \\
\hline ATGCACATCG & 0.01 & 0.02 & 0.013 & 0.138 \\
\hline ATGCGTCCCA & 0.01 & 0.01 & 0.012 & 0.380 \\
\hline ACGCGTCCGA & 0.005 & 0.01 & 0.007 & 0.570 \\
\hline GCGCGCCCGT & 0.01 & 0.004 & $0.007^{c}$ & 0.253 \\
\hline GCAAGCACCA & 0.01 & 0.002 & $0.006^{d}$ & 0.745 \\
\hline ATGAACCCGA & 0.01 & 0 & $0.006^{\mathrm{e}}$ & 0.245 \\
\hline ACGAGTCCCA & 0.01 & 0 & $0.006^{\mathrm{f}}$ & 0.835 \\
\hline ACGCACCCCA & 0.08 & 0.07 & 0.006 & 0.276 \\
\hline
\end{tabular}

${ }^{\text {a Haplotypes with a frequency } \geq 0.005}$

SNPs found to be in common with previous studies:

${ }^{\mathrm{b}} \mathrm{V}-2$.

'V_4, ST_+4.

d $V_{-}^{-}-1, S_{-} 1$.

eV_4, ST+7, Q $-1, \mathrm{~F}_{-}+1$

'ST $-7, S_{-}+4, F_{-}+1$.

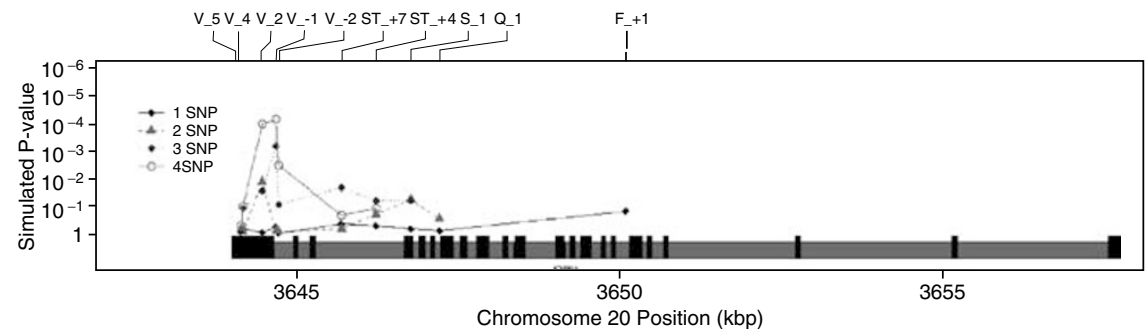

Figure 1 Plot of simulated $P$-values for testing haplotypic associations with asthma. The taller boxes along the $X$ axis denote exons and the shorter boxes, the introns, of the ADAM33 gene. The tics along the upper axis give the position and names of the genotyped SNPs. The legend shows the sliding window comprising 1, 2, 3 or 4 consecutive SNPs, each tested for association in turn.

polymorphisms in the ADAM33 gene, previously shown to be associated with asthma, in a large Australian Caucasian population of mild, moderate and severe asthmatics and nonasthmatic controls. Analysis of these SNPs, using an ordinal logistic regression model, revealed no association between any one of the polymorphisms and asthma severity. However, a score-based omnibus test for haplotypic association showed a significant association with asthma $(P=0.0002)$ and with asthma severity $(P=0.0001)$ in this population, driven especially by variation at the $V_{-} 4$ to $\mathrm{V}_{-}-1$ SNPS.

The ADAM proteins are type-I transmembrane proteins and a subgroup of the metzincin metalloproteinase superfamily, ${ }^{9,10}$ with a disintegrin and a metalloproteinase domain. These proteins are thought to be involved in adhesive interactions, cell fusion and proteolysis, ${ }^{10,28-30}$ all processes involved in tissue remodelling. Recent studies of ADAM33 have suggested that it has a particularly important role in airway remodelling and BHR. ${ }^{13,14}$ It is expressed in lung fibroblasts, heart and bronchial smooth muscle, but not in bronchial epithelial cells. ${ }^{13,30}$ In asthmatic lungs, it is similarly expressed in bronchial smooth muscle cells and fibroblasts, underlying the respiratory epithelium, and it is likely that the effects of ADAM33 on the repairing epithelium in the asthmatic lung are indirect, through expression and activity within the underlying submucosal smooth muscle layer. ${ }^{14}$ The metzincin family of metalloproteinases also includes matrix metalloproteinases (MMPs), specifically regulated by tissue inhibitors of metalloproteinases (TIMPs) during tissue remodelling. Although the physiological significance is unclear, a number of ADAMs are also inhibited 
Table 5b Observed and expected counts of $V_{-}-1$ and ST_+7 joint unphased genotypes in an Australian population

\begin{tabular}{|c|c|c|c|c|c|}
\hline$V_{-}-1$ genotype & $S T_{-}+7$ genotype & Asthma status & Observed & Predicted & Deviance residual \\
\hline \multirow[t]{2}{*}{ GG } & $\mathrm{CC}$ & Asthma & 255 & 246.2 & 0.56 \\
\hline & & Nonasthma & 316 & 324.8 & -0.49 \\
\hline \multirow[t]{2}{*}{ GT } & $\mathrm{CC}$ & Asthma & 2 & 9.5 & -2.96 \\
\hline & & Nonasthma & 20 & 12.5 & 1.95 \\
\hline \multirow[t]{2}{*}{ TT } & $\mathrm{CC}$ & Asthma & 0 & 1.3 & -1.63 \\
\hline & & Nonasthma & 3 & 1.7 & 0.93 \\
\hline \multirow[t]{2}{*}{ GG } & CT & Asthma & 35 & 43.2 & -1.29 \\
\hline & & Nonasthma & 64 & 55.8 & 1.07 \\
\hline \multirow[t]{2}{*}{ GT } & $\mathrm{CT}$ & Asthma & 86 & 77.8 & 0.91 \\
\hline & & Nonasthma & 92 & 100.2 & -0.83 \\
\hline \multirow[t]{2}{*}{ TT } & $\mathrm{CT}$ & Asthma & 0 & 0.0 & 0.00 \\
\hline & & Nonasthma & 0 & 0.0 & 0.00 \\
\hline \multirow[t]{2}{*}{ GG } & $\pi$ & Asthma & 3 & 3.7 & -0.36 \\
\hline & & Nonasthma & 4 & 3.3 & 0.35 \\
\hline \multirow[t]{2}{*}{ GT } & $\pi$ & Asthma & 3 & 3.7 & -0.36 \\
\hline & & Nonasthma & 4 & 3.3 & 0.36 \\
\hline \multirow[t]{3}{*}{ TT } & $\pi$ & Asthma & 11 & 9.7 & 0.42 \\
\hline & & Nonasthma & 7 & 8.3 & -0.48 \\
\hline & & \multicolumn{4}{|c|}{ Overall $X^{2}=21.88(\mathrm{df}=4), P=0.00016$} \\
\hline
\end{tabular}

Table 6 Comparison of common ADAM33 haplotypes between Caucasian populations

\begin{tabular}{|c|c|c|c|c|c|c|}
\hline \multirow[b]{2}{*}{$\begin{array}{l}\text { Shared } \\
\text { haplotype }^{\mathrm{a}}\end{array}$} & \multicolumn{2}{|c|}{ Dutch $^{16}$} & \multicolumn{2}{|c|}{ US Caucasian ${ }^{16}$} & \multicolumn{2}{|c|}{ Australian Caucasian } \\
\hline & $\begin{array}{c}\text { Asthma } \\
(n=197)\end{array}$ & $\begin{array}{c}\text { Nonasthma } \\
\text { controls }(n=146)\end{array}$ & $\begin{array}{c}\text { Asthma } \\
(n=227)\end{array}$ & $\begin{array}{c}\text { Nonasthma } \\
\text { controls }(n=244)\end{array}$ & $\begin{array}{c}\text { Asthma } \\
(n=612)\end{array}$ & $\begin{array}{c}\text { Nonasthma } \\
\text { controls }(n=473)\end{array}$ \\
\hline GAGCC & 0.475 & 0.496 & 0.495 & 0.494 & 0.47 & 0.45 \\
\hline GCGCC & 0.236 & 0.229 & 0.194 & 0.184 & 0.18 & 0.20 \\
\hline GCGCG & 0.153 & 0.065 & 0.132 & 0.119 & 0.115 & 0.114 \\
\hline AAAAG & 0.071 & 0.082 & 0.084 & 0.090 & 0.08 & 0.09 \\
\hline GCACC & 0.038 & 0.086 & 0.051 & 0.064 & 0.12 & 0.12 \\
\hline GCAAC & 0.020 & 0.027 & 0.031 & 0.029 & 0.01 & 0.02 \\
\hline AAGAC & 0 & 0 & 0 & 0 & 0.01 & 0.002 \\
\hline GAACG & 0 & 0 & 0 & 0 & 0.01 & 0 \\
\hline
\end{tabular}

${ }^{a}$ Common haplotype: $S_{-} 1, S_{-}+4, S_{-}+7, V_{-}-1, V_{-} 4$.

by the TIMPs and, more specifically, ADAM33 activity has been shown to be inhibited by TIMP-3 and -4 , slightly by TIMP-2, but not by TIMP-1. ${ }^{31}$

The ADAM33 gene has been mapped to chromosome $20 \mathrm{p} 13$, and has an open reading of $2442 \mathrm{bp}$, consisting of 22 exons. ${ }^{30}$ Numerous SNPs have been described in the gene $^{13,32}$ and several have been found to be associated with asthma and BHR in Caucasian populations from the UK, the US, Holland and Germany, using case-control, TDT (transmission/disequilibrium test) and haplotype analyses. ${ }^{13,16,27}$ Of the 37 polymorphisms in ADAM33, studied by Van Eerdewegh et al, ${ }^{13}$ six were found to be significantly associated with asthma in a combined the UK/US casecontrol population, and haplotype pair analysis in this population revealed five pairs of SNPs to be significantly associated with asthma at the $P<0.001$ level and a further 23 pairs to be significant at the $P \leq 0.01$ level. Positive associations have also found between some of these polymorphisms and asthma in African Americans and Hispanics, ${ }^{16}$ BHR in American Caucasians ${ }^{16}$ and Koreans, ${ }^{33}$ and atopy and longitudinal $\mathrm{FEV}_{1}$ decline in Dutch populations, ${ }^{16,34}$ allergic rhinitis in a Japanese population, ${ }^{35}$ and have also been reported in a German population. ${ }^{27,36}$ Interestingly, a recent study in Puerto Rican and Mexican populations failed to show an association between ADAM33, asthma, asthma severity and atopy in these populations (Table 4). ${ }^{37}$ Similarly, a study in a large population of childhood asthmatic subjects representative of a North American population with mild to moderate asthma, failed to show significant single-SNP associations between ADAM33 and either asthma or airways responsiveness. $^{38}$

Unlike Van Eerdewegh et $a l^{13}$ we did not detect association between any single SNP in the ADAM33 gene and asthma in our large Australian Caucasian population; nor was there an association between polymorphisms in ADAM33 and the atopic phenotype. This argues that the association between ADAM33 and asthma is presumably not mediated through the intermediate phenotype of atopy, in keeping with its suspected function. Our study 
is well powered, with the widest 95\% confidence interval on the allelic odds ratio (for $\mathrm{V} \_2$ ) running from 0.6 to 1.7 (and average interval 0.78-1.33), so we believe we have not overlooked any large effects of individual SNPs.

In their combined population, Van Eerdewegh et al, ${ }^{13}$ found the single most significantly associated SNP to be $\mathrm{V}_{-}-1$. Although we did not find a significant association with this SNP alone in our population, $\mathrm{V}_{-}-1 / \mathrm{ST}_{-}+7$ gave the most significant haplotypic result $(P=0.00016)$. Van Eerdewegh et al, also found this haplotype to be associated with asthma $(P=0.02),{ }^{13}$ although their most significantly associated haplotype in their combined population was ST $+4 / \mathrm{V}-3(P=0.00004)$. In accord with most previous studies in Causasian populations, we found our strongest evidence for associations was between $A D A M 33$ haplotypes and asthma and asthma severity, rather than with single SNPs and despite the apparently high level of LD between the polymorphisms. When we examined shorter haplotypes (using a sliding window approach, illustrated in Figure 1), there was some overlap of SNPs included in the most strongly associated sets, and those found to be associated with asthma in previous studies, including $\mathrm{V}_{-}-1$ and ST $+7 .^{13,16,27}$ Cox et al, ${ }^{39}$ have compared ADAM33 to calpain 10 (CAPN10) and NOD2. These are two other cases where haplotypes made up of noncoding variants, but not single SNPs, have been associated with disease phenotypes in a complex fashion.

The finding of association with asthma in the Australian population appeared to have been driven by five less common haplotypes, which together made up $4 \%$ of the haplotypes in the asthmatics. A comparison of haplotypes constructed using the SNPs simultaneously investigated in Australian, Dutch and American Caucasian populations, showed that the same five haplotypes are commonest in all three populations, suggesting that these populations are broadly comparable with respect to their genetic structure. Meta-analysis of the haplotypic frequencies found statistically significant differences in the minor haplotype frequencies, although it revealed a similar trend of rare haplotype frequencies in all three populations. It is difficult to speculate as to the functional importance of the rare haplotypes found to be associated with asthma in our Australian population. This population was principally Caucasian, however, it is remotely possible that the rare haplotypes represent occult admixture between populations with significantly different risks of asthma.

In our analysis for association of ADAM33 haplotype with disease severity, we were looking for a dose-response effect as one might expect that gene variants associated with increased airway remodelling, as suggested by Jongepier et al, ${ }^{34}$ to be likewise increased in more severe asthma. Thus, our analysis included the controls/nonasthma group as we would expect increasing frequency of associated alleles and/or haplotypes when going from the least to most severe phenotype. However, despite the suggestion that $A D A M 33$ may act as a modifying gene, ${ }^{34}$ in our population $A D A M 33$ haplotype did not seem to modify asthma severity per se, as differences in haplotype frequency were only significant between asthmatics and controls, and not within the different clinical groups.

SNP frequencies in the ADAM33 gene differ somewhat between populations, most significantly between different ethnic groups, possibly reflecting differences in the genetic basis of asthma in ethnically diverse populations. ${ }^{37}$ It is interesting to speculate that, while ADAM33 gene has a potential role as an asthma susceptibility and/or modifying locus, the effect of ADAM33 on asthma cannot be large precisely because ethnic differences in SNP allele frequencies would need to equate to equally large differences in asthma prevalence.

Many of the studies published to date have used different genotyping technologies, including a combination of automated single stranded conformational polymorphism (SSCP) analysis, exonuclease proofreading methods, restriction fragment length polymorphisms (RFLP) analysis, allele-specific oligonucleotide hybridisation (ASO), automated fluorescence resonance energy transfer (FRET) detection and MALDI-TOF mass spectrometry to type these SNPs in large populations. ${ }^{13,16,27,37}$ The consistent genotype frequencies observed across the different Caucasian populations suggest that any of the SNP-typing technologies used are accurate. However, we have used MALDI-TOF mass spectrometry, as we are confident that this technique is a reliable, high volume genotyping method, ${ }^{40,41}$ maintaining a high level of accuracy, even with multiplexed assays. ${ }^{40,42,43}$

Of the numerous polymorphisms described in the ADAM33 gene, 11 occur in the coding region and, of these, nine are nonsynonymous. It has been proposed that some of the ADAM33 polymorphisms may affect alternative splicing, splicing efficiency or mRNA turnover ${ }^{13}$ and hence accelerate the proliferation of smooth muscle cells and fibroblasts, leading to bronchial hyperreactivity and subepithelial fibrosis. ${ }^{44-46}$ It has also been suggested that those in the $3^{\prime}$ UTR may be significant, ${ }^{36}$ although functional investigations of some of the $3^{\prime} \mathrm{UTR}$ polymorphisms have so far been unsuccessful. ${ }^{14}$ The actual functional significance of most of the polymorphisms in the ADAM33 gene has yet to be elucidated. It is worth noting that few have been shown to be associated with asthma in the populations screened to date, further suggesting that the causative mutation in ADAM33 has not yet been identified. It is important to note that these findings do not exclude the possibility that there are as yet unidentified functional variants either within the ADAM33 gene, or in a nearby gene, and that these associations are caused by LD. ${ }^{38}$

In conclusion, despite an adequately powered study, we have not been able to demonstrate association between any one of the ADAM33 SNPs studied and asthma, asthma severity or atopy in an Australian Caucasian population. 
However, and in agreement with a number of other studies, we have shown a significant association between ADAM33 haplotypes and asthma. Although it does not exclude an association with another locus in LD with ADAM33, this finding does suggest a likely role for ADAM33 in the asthma phenotype.

\section{Acknowledgements}

We would like to thank all the people who participated in this study and the staff at AARI and Sir Charles Gairdner Hospital in Perth, Australia, who assisted with the collection of clinical information and blood samples.

\section{References}

1 Busse WW, Lemanske RF: Asthma. New Engl J Med 2001; 344: 350-362.

2 Fahy JV: Remodeling of the airway epithelium in asthma. Am J Respir Crit Care Med 2001; 164: S46-S51.

3 Holgate ST, Davies DE, Lackie PM, Wilson SJ, Puddicombe SM, Lordan JL: Epithelial-mesenchymal interactions in the pathogenesis of asthma. J Allergy Clin Immunol 2000; 105: 193-204.

4 Elias JA, Zhu Z, Chupp G, Homer RJ: Airway remodeling in asthma. J Clin Invest 1999; 104: 1001-1006.

5 Lange P, Parner J, Vestbo J, Schnohr P, Jensen G: A 15-year followup study of ventilatory function in adults with asthma. $N$ Engl $J$ Med 1998; 339: 1194-1200.

6 O'Hara KA, Kedda MA, Thompson PJ, Knight DA: Oncostatin M: an interleukin-6-like cytokine relevant to airway remodelling and the pathogenesis of asthma. Clin Exp Allergy 2003; 33: $1026-1032$.

7 Nath D, Slocombe PM, Stephens PE et al: Interaction of metargidin (ADAM-15) with alphavbeta3 and alpha5beta1 integrins on different haemopoietic cells. J Cell Sci 1999; 112 (Part 4): 579-587.

8 Chen MS, Tung KS, Coonrod SA et al: Role of the integrinassociated protein CD9 in binding between sperm ADAM 2 and the egg integrin alpha6beta1: implications for murine fertilization. Proc Natl Acad Sci USA 1999; 96: 11830-11835.

9 Stone AL, Kroeger M, Sang QX: Structure-function analysis of the ADAM family of disintegrin-like and metalloproteinase-containing proteins (review). J Protein Chem 1999; 18: 447-465.

10 Primakoff P, Myles DG: The ADAM gene family: surface proteins with adhesion and protease activity. Trends Genet 2000; 16: $83-87$

11 Orth P, Reichert P, Wang W et al: Crystal structure of the catalytic domain of human ADAM33. J Mol Biol 2004; 335: 129-137.

12 Black RA, Rauch CT, Kozlosky CJ et al: A metalloproteinase disintegrin that releases tumour-necrosis factor-alpha from cells. Nature 1997; 385: 729-733.

13 Van Eerdewegh P, Little RD, Dupuis J et al: Association of the ADAM33 gene with asthma and bronchial hyperresponsiveness. Nature 2002; 418: 426-430.

14 Umland SP, Garlisi CG, Shah $\mathrm{H}$ et al: Human ADAM33 mRNA expression profile and post- transcriptional regulation. Am J Respir Cell Mol Biol 2003; 29: 571-582.

15 Garlisi CG, Zou J, Devito KE et al: Human ADAM33: protein maturation and localization. Biochem Biophys Res Commun 2003; 301: $35-43$.

16 Howard TD, Postma DS, Jongepier $\mathrm{H}$ et al: Association of a disintegrin and metalloprotease 33 (ADAM33) gene with asthma in ethnically diverse populations. J Allergy Clin Immunol 2003; 112: $717-722$

17 Storm N, Darnhofer-Patel B, van den Boom D, Rodi CP: MALDITOF mass spectrometry-based SNP genotyping. Methods Mol Biol 2003; 212: 241-262.

18 Kedda MA, Shi J, Duffy DL et al: Characterisation of two polymorphisms in the LTC4 synthase gene in an Australian population of mild, moderate and severe asthmatics. J Allergy Clin Immunol 2004; 113: 889-895.

19 Asthma Management Handbook. Australian National Asthma Council (http://www.nationalasthma.org.au/) 2002.

20 Expert Panel Report II: Practical Guide for the diagnosis and management of asthma. National Asthma Education and Prevention Program, National Heart, Lung and Blood Institute 1997, IH publication 99-4055A.

21 Dudbridge F: Pedigree disequilibrium tests for multilocus haplotypes. Genet Epidemiol 2003; 25: 115-121.

22 Schaid DJ, Rowland CM, Tines DE, Jacobson RM, Poland GA: Score tests for association between traits and haplotypes when linkage phase is ambiguous. Am J Hum Genet 2002; 70: 425-434.

23 R Development Core Team. R: A language and environment for statistical computing, R Foundation for Statistical Computing, Vienna, Austria, http://www.R-project.org, 2003.

24 Caffo B exactLoglinTest: Monte Carlo Exact Tests for Log-linear models, R package version 1.3.2, URL: http://www.biostat. jhsph.edu/ bcaffo, 2004.

25 Booth JD, Butler RW: An importance sampling algorithm for exact conditional tests in log-linear models. Biometrika 1999; 86: 321-332.

26 Howard TD, Meyers DA, Ampleford EA et al: Association of ADAM33 with asthma and associated phenotypes in ethnically diverse populations. Am J Hum Genet 2002; 71: 488.

27 Werner M, Herbon N, Gohlke $\mathrm{H}$ et al: Asthma is associated with single-nucleotide polymorphisms in ADAM33. Clin Exp Allergy 2004; 34: 26-31

28 Wolfsberg TG, Primakoff P, Myles DG, White JM: ADAM, a novel family of membrane proteins containing A Disintegrin And Metalloprotease domain: multipotential functions in cell-cell and cell-matrix interactions. J Cell Biol 1995; 131: 275-278.

29 Howard L, Maciewicz RA, Blobel CP: Cloning and characterization of ADAM28: evidence for autocatalytic pro- domain removal and for cell surface localization of mature ADAM28. Biochem J 2000; 348 (Part 1): 21-27.

30 Yoshinaka $\mathrm{T}$, Nishii $\mathrm{K}$, Yamada $\mathrm{K}$ et al: Identification and characterization of novel mouse and human ADAM33s with potential metalloprotease activity. Gene 2002; 282: 227-236.

31 Zou J, Zhu F, Liu J et al: Catalytic activity of human ADAM33 (A disintegrin and metalloproteinase). J Biol Chem 2004; 279: 9818-9830.

32 Chae SC, Yoon KH, Chung HT: Identification of novel polymorphisms in the Adam33 gene. J Hum Genet 2003; 48: 278-281.

33 Lee JH, Park HS, Park SW et al: ADAM33 polymorphism: association with bronchial hyper-responsiveness in Korean asthmatics. Clin Exp Allergy 2004; 34: 860-865.

34 Jongepier H, Boezen HM, Dijkstra A et al: Polymorphisms of the ADAM33 gene are associated with accelerated lung function decline in asthma. Clin Exp Allergy 2004; 34: 757-760.

35 Cheng L, Enomoto T, Hirota T et al: Polymorphisms in ADAM33 are associated with allergic rhinitis due to Japanese cedar pollen. Clin Exp Allergy 2004; 34: 1192-1201.

36 Holgate ST, Davies DE, Murphy G, Powell RM, Holloway JW: ADAM 33: just another asthma gene or a breakthrough in understanding the origins of bronchial hyperresponsiveness? Thorax 2003; 58: 466-469.

37 Lind DL, Choudhry S, Ung N et al: ADAM33 is not associated with asthma in Puerto Rican or Mexican populations. Am J Respir Crit Care Med 2003; 168: 1312-1316.

38 Raby BA, Silverman EK, Kwiatkowski DJ, Lange C, Lazarus R, Weiss ST: ADAM33 polymorphisms and phenotype associations in childhood asthma. J Allergy Clin Immunol 2004; 113: 1071-1078.

39 Cox NJ, Hayes MG, Roe CA, Tsuchiya T, Bell GI: Linkage of calpain 10 to type 2 diabetes: the biological rationale. Diabetes 2004; 53 (Suppl 1): S19-S25.

40 Bray MS, Boerwinkle E, Doris PA: High-throughput multiplex SNP genotyping with MALDI-TOF mass spectrometry: practice, problems and promise. Hum Mutat 2001; 17: 296-304.

41 Buetow KH, Edmonson M, MacDonald R et al: High-throughput development and characterization of a genomewide collection of 
gene-based single nucleotide polymorphism markers by chip-based matrix-assisted laser desorption/ionization time-offlight mass spectrometry. Proc Natl Acad Sci USA 2001; 98: $581-584$.

42 Nakai K, Habano W, Fujita T et al: Highly multiplexed genotyping of coronary artery disease-associated SNPs using MALDI-TOF mass spectrometry. Hum Mutat 2002; 20: 133-138.

43 James MR, Hayward NK, Dumenil T, Montgomery GW, Martin NG, Duffy DL: Epidermal growth factor gene (EGF) polymorph- ism and risk of melanocytic neoplasia. I Invest Dermatol 2004; 123: $760-762$.

44 Shapiro SD, Owen CA: ADAM-33 surfaces as an asthma gene. $N$ Engl J Med 2002; 347: 936-938.

45 Drazen JM, Weiss ST: Genetics: inherit the wheeze. Nature 2002; 418: $383-384$.

46 Davies DE, Wicks J, Powell RM, Puddicombe SM, Holgate ST: Airway remodeling in asthma: new insights. $J$ Allergy Clin Immunol 2003; 111: 215-225; quiz 226. 